\title{
PETROLOGY AND GEOCHEMISTRY OF CALC-SILICATE SCHISTS AND CALC-SILICATE REACTION BANDS IN THE JAKURA MARBLE, WESTERN NIGERIA
}

C. T. OKONKWO

(Received 29 February 2012; Revision Accepted 15 May 2012)

\begin{abstract}
The Jakura Marble deposit is located ca. $50 \mathrm{~km}$ northwest of Lokoja, southwestern Nigeria. Calc-silicate schists occur as intercalations and lenses within the marble. The schists consist of hornblende, biotite, actinolite, plagioclase, quartz, accessory epidote, sphene, zircon, chlorite and apatite. Calc-silicate reaction bands developed at the contacts between the marble and calc-silicate schists consist of diopside, plagioclase, scapolite, late actinolite and epidote.

Chemically the calc-silicate schists are characterized by relatively high $\mathrm{CaO}, \mathrm{MgO}, \mathrm{Cr}, \mathrm{Ni}, \mathrm{Sr}, \mathrm{La}, \mathrm{Ce}$ and $\mathrm{Nd}$ contents compared with the mica schist regionally associated with the marble as well as the Post-Archean Australian Shale (PAAS). Relative to the ultramafic schist the calc-silicate schists are characterized by higher contents of $\mathrm{K}_{2} \mathrm{O}$, $\mathrm{Ba}, \mathrm{Pb}, \mathrm{Rb}, \mathrm{La}$ and $\mathrm{Ce}$ and lower $\mathrm{MgO}, \mathrm{CaO}, \mathrm{Fe}, \mathrm{Na}_{2} \mathrm{O}, \mathrm{Cr}$ and $\mathrm{V}$. The calc-silicate reaction bands have higher contents of $\mathrm{CaO}$ and $\mathrm{Sr}$ and lower concentrations of $\mathrm{K}_{2} \mathrm{O}, \mathrm{Rb}, \mathrm{Ni}$, and $\mathrm{Ba}$ relative to the calc-silicate schists; and relatively higher $\mathrm{SiO}_{2}, \mathrm{TiO}_{2}, \mathrm{Al}_{2} \mathrm{O}_{3}, \mathrm{Fe}_{2} \mathrm{O}_{3}, \mathrm{MgO}, \mathrm{Na}_{2} \mathrm{O}, \mathrm{K}_{2} \mathrm{O}$ and $\mathrm{P}_{2} \mathrm{O}_{5}$ and lower $\mathrm{CaO}$ contents compared to the marble.

These features suggest that the protoliths of the calc-silicate schists were admixtures of carbonate material with some ultramafic detritus, and the reaction band was produced by diffusion of elements from the calc-silicate schists into the marble contact zone.
\end{abstract}

KEY WORDS: Jakura, Calc-silicate Schists, Calc-silicate Reaction Bands, Marble, Geochemistry

\section{INTRODUCTION}

Calc-silicate schists and calc-silicate reaction bands are commonly associated with metacarbonate rock deposits. The reaction bands are generally developed at the contact between the schists and the metacarbonate rock bodies. The rea ction bands characterized by calc-silicate minerals are regarded as products of metasomatic processes involving diffusive transfer of chemical components between the metacarbonate body and the schist ( Thompson 1975, Ague 2003).

The composition of the calc-silicate schists are generally variable and are dependent on the compositions of the pre-metamorphic protoliths which are derived by the admixtures of the argillaceous sediments with carbonate materials or with some basic or ultrabasic igneous material or due to large-scale metasomatism (van de Kamp 1968, Leake 1980, Vearnecombe 1983, Ferguson and Al-Ameen 1986).

This paper investigates the calc-silicate schists and the calc-silicate bands which occur as intercalations in the Jakura Marble deposit, western Nigeria with a view to determining their petrological and geochemical characteristics as well as their petrogeneses.

\section{GEOLOGICAL SETTING}

The Nigerian basement complex forms part of the internal zone of the Neoproterozoic mobile belt east of the West African craton (Fig. 1). Relatively low-grade metamorphosed schist belts are a major lithotectonic unit in the western part of the basement complex. These generally N-S trending belts are bordered by migmatitegneiss units and both have been intruded by largely undeformed granitic rocks of Pan-African (ca $600 \mathrm{Ma}$ ) age. Some of these belts especially those in central part of the basement complex contain large metacarbonate bodies. The Lokoja-Jakura Schist belt (Okunlola and Elueze 2003) is one of such belts hosting a large metacarbonate body- the Jakura marble deposit.

On the basis of lithological association, Turner (1983) has interpreted the schist belt to represent originally well-sorted shelf and littoral deposits. Although there is no geochronological evidence for its age, Turner (1983) has suggested a Mesoproterozoic age on the basis of its complex structural trends and the intrusive relations of the Pan-African granitic rocks.

The Jakura marble deposit is a calcitic marble body interbanded on the large scale with quartz-mica schists, phyllites and biotite-hornblende gneisses with thin quartzite intercalations (Fig.2). Granitic rocks 
including pegmatites of assumed Neoproterozoic age emplced during the Pan-African orogeny also intruded these metamorphic rocks. The marble and associated rocks have been deformed and form part of the western limb of an antiformal fold with a N-S trending axis (Hazel 1956). Locally, the rocks have been tectonised within late-tectonic shear zones with shear foliations subparallel to the N-S structural trends of the country rocks (Hazell 1956). Late faults have also, locally, displaced the marble and associated rocks.

\section{PETROGRAPHY OF THE CALC-SILICATE SCHISTS AND THE CALC-SILICATE BANDS}

The schists are dark grey, strongly foliated, medium-grained rocks which consist of hornblende, biotite, actinolite, plagioclase, quartz and accessory sphene, epidote, apatite, chlorite and zircon. Biotite and hornblende define a strong foliation (S1) which is overprinted by randomly oriented grains of late biotite and actinolite. Late biotite tends to be porphyroblastic and occasionally contains inclusions of some early (S1 fabric) minerals. Actinolite in slender prisms overgrows early hornblende. These mineral assemblages indicate a syntectonic amphibolite facies regional metamorphism which was later overprinted by a retrograde greenschist facies event.

The calc-silicate bands developed between the marble and the calc-silicate schists have variable thickness from $1 \mathrm{~cm}$ to $2 \mathrm{~cm}$ which may show some zoning. At the border with marble are coarse crystals of plagioclase and diopside as well as some calcite. Retrograde overgrowths of actinolite, chlorite, epidote occasionally mantle these primary minerals. Scapolite occurs occasionally in some bands.

\section{GEOCHEMISTRY}

Six samples of the calc-silicate schists, three samples of the calc-silicate bands and two samples of the ultramafic schist were selected for chemical analyses. Both major and trace elements were analysed by X-Ray Fluorescence Spectrometry at the University of Keele. England and at the Technical University, Berlin, Germany.

\section{Schists-Major Elements}

The major element compositions of the samples of the calc-silicate schists, calc-silicate bands and the ultramafic schist are presented in Table 1, while the mean chemical compositions of these rocks as well as those of the associated mica schist (Elueze and Okunlola 2003), marble (Elueze and Okunlola 2003) and Average Post-Archean Australian Shale (PAAS, Taylor and McLennan 1985) are presented in Table 2.

The calc-silicate schists are highly enriched in $\mathrm{MgO}(\mathrm{x}$ $=7.44), \mathrm{CaO}(\mathrm{x}=7.78), \mathrm{Na}_{2} \mathrm{O}(\mathrm{x}=3.32)$ and $\mathrm{P}_{2} \mathrm{O}_{5}(\mathrm{x}$ $=0.64$ ) compared to the mica schist (Table 2 and Fig. 3 ), and the average PAAS (Table 2 and Fig. 4). They are however slightly depleted in $\mathrm{SiO}_{2}(\mathrm{x}=52.22)$ compared to the mica schist and the PAAS, and in $\mathrm{Al}_{2} \mathrm{O}_{3}$ compared to the PAAS (Table 2, Figs. 3 and 4).

Compared to the ultramafic schist, the calc-silicate schists are enriched in $\mathrm{TiO}_{2}, \mathrm{Al}_{2} \mathrm{O}_{3}, \mathrm{Na}_{2} \mathrm{O}, \mathrm{K}_{2} \mathrm{O}, \mathrm{P}_{2} \mathrm{O}_{5}$ and depleted in $\mathrm{Fe}_{2} \mathrm{O}_{3}, \mathrm{MgO}$ and $\mathrm{CaO}$ (Table 2 and Fig. 5).

\section{Schists-Trace Elements}

The trace element compositions of the calcsilicate schists, calc-silicate bands and the ultramafic schist are also presented in Table 1 while Table 2 shows their mean compositions as well as those of the mica schist (Elueze and Okunlola 2003), Jakura marble (Elueze and Okunlola 2003) and the average PAAS (Taylor and McLennan 1985). The calc-silicate schists are highly enriched in $\mathrm{Ba}(\mathrm{x}=2778), \mathrm{Cr}(\mathrm{x}=388), \mathrm{Ni}(\mathrm{x}$ $=601), \operatorname{Sr}(x=2520), \mathrm{La}(\mathrm{x}=131), \mathrm{Ce}(\mathrm{x}=366)$ and $\mathrm{Nd}(\mathrm{x}$ $=124)$ compared to the PAAS (Table 2 and Fig. 4). Compared to the ultramafic schist the calc-silicate schists are enriched in $\mathrm{Ba}, \mathrm{Cu}, \mathrm{Ga}, \mathrm{Nb}, \mathrm{Pb}, \mathrm{Rb}, \mathrm{Sr}, \mathrm{Zr}$, $\mathrm{La}, \mathrm{Ce}$ and $\mathrm{Nd}$ (Table 2 and Fig 5).

\section{Calc-silicate bands- Major Elements}

The calc-silicate bands are relatively enriched in $\mathrm{CaO}$, and depleted in $\mathrm{Al}_{2} \mathrm{O}_{3}, \mathrm{Na}_{2} \mathrm{O}, \mathrm{K}_{2} \mathrm{O}$, compared to the calc-silicate schists (Table 2 and Fig. 6). They are also relatively enriched in $\mathrm{SiO}_{2}, \mathrm{TiO}_{2}, \mathrm{Al}_{2} \mathrm{O}_{3}, \mathrm{Fe}_{2} \mathrm{O}_{3}$, $\mathrm{MnO}, \mathrm{MgO}, \mathrm{Na}_{2} \mathrm{O}_{3}, \mathrm{~K}_{2} \mathrm{O}$ and $\mathrm{P}_{2} \mathrm{O}_{5}$ and depleted in $\mathrm{CaO}$ compared to the marble (Table 2 and Fig. 7 ).

\section{Calc-silicate bands- Trace Elements}

The calc-silicate bands are enriched in $\mathrm{Sr}$ but depleted in $\mathrm{Ba}, \mathrm{Cr}, \mathrm{Ni}, \mathrm{Pb}, \mathrm{Rb}, \mathrm{V}, \mathrm{Y}, \mathrm{Zn}, \mathrm{Zr}, \mathrm{La}, \mathrm{Ce}$ and $\mathrm{Nd}$ relative to the calc-silicate schists (Table 2 and Fig. 7).

\section{DISCUSSION}

The very high contents of $\mathrm{MgO}, \mathrm{Cr}$ and $\mathrm{Ni}$ in the calc-silicate schists suggest mafic/ utramafic sources for part of the protoliths of the schists. The very high contents of $\mathrm{CaO}$ and $\mathrm{Sr}$ suggest sources related to the main carbonate deposit i.e. the limestone protolith of the marble. Very high $\mathrm{Ba}$ is suggestive of a K-feldspar-rich protolith because of the very strong $\mathrm{Ba}$ positive correlation with $\mathrm{K}_{2} \mathrm{O}$. The high $\mathrm{Na}_{2} \mathrm{O}$ contents of these schists may be attributed to metasomatic introduction from seawater during spilitisation of the mafic/ultramafic detritus (van de Kamp and Leake 1986). The protoliths of the schists therefore seem to be a mixture of $\mathrm{K}_{2} \mathrm{O}$-rich mafic/ultramafic detritus and some carbonate-derived material.

The composition of the calc-silicate bands relative to the calc-silicate schists and the marble suggests diffusion/ migration of certain elements i.e. $\mathrm{SiO}_{2}, \mathrm{TiO}_{2}, \mathrm{Al}_{2} \mathrm{O}_{3}, \mathrm{Fe}_{2} \mathrm{O}_{3}, \mathrm{MnO}, \mathrm{MgO}, \mathrm{Na}_{2} \mathrm{O}, \mathrm{K} \mathrm{O}_{2}, \mathrm{P}_{2} \mathrm{O}_{5}$, $\mathrm{Ba}, \mathrm{Cr} \mathrm{Ni}, \mathrm{Pb}, \mathrm{Rb}, \mathrm{V}, \mathrm{Y}, \mathrm{Zn}, \mathrm{Zr}$, La, Ce and $\mathrm{Nd}$ from the schists into the contact zone of the marble. These are similar to calc-silicate reaction zones between marbles and pelitic schists documented by Thompson (1975)

\section{Sedimentary depositional model for the calc-silicate schists}

Field relations show that the calc-silicate schists occur as intercalations within the marble. Also the marble is on a larger scale interlayered within mica schists containing bands of metamorphosed mafic/ultramafic schists believed to represent volcanics. These stratigraphic relationships suggest a submarine shelf depositional environment for the Jakura area in Precambrian times. Swells on the shelf were sites of limestone (carbonate) deposition and the associated 
basins were sites of deposition of argillaceous material along with periods of volcanic activity. Intermittently, clastic material derived from the igneous rocks were deposited on the carbonate swells as they subsided between prolonged periods of carbonate deposition. Thus admixtures of mafic detritus and carbonate material formed the protoliths of the schists.

The model outlined above is similar to those proposed by van de Kamp (1968) for the metasedimentary rocks of the Haliburton-Madoc area, Ontario, Canada; Vearnecombe (1983) for the hornblende and mica schists intercalated with marble in western Kenya, and Ferguson and Al-Ameen (1986) for the metasedimentary rocks of Connemara area, Ireland.

\section{ACKNOWLEDGEMENTS}

I thank Dr G. Mattheis of Technical University, Berlin, Germany, Prof. S O. Akande and Prof. J. A. Winchester, Keele University, England for analytical assistance.

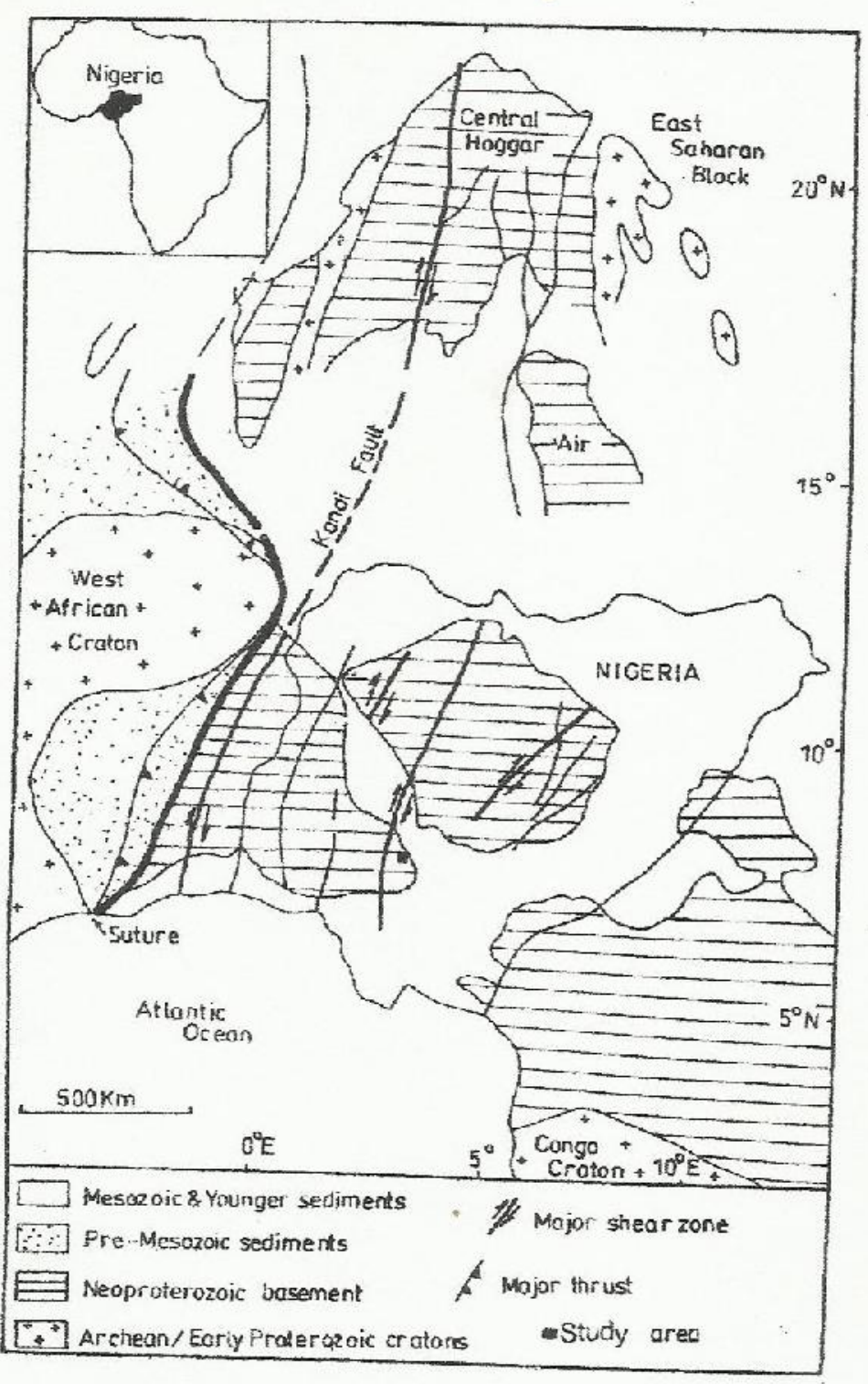

Fig. 1. Index map of the Nigeria within the Trans-Saharan mobile belt showing the location of Jakura area 


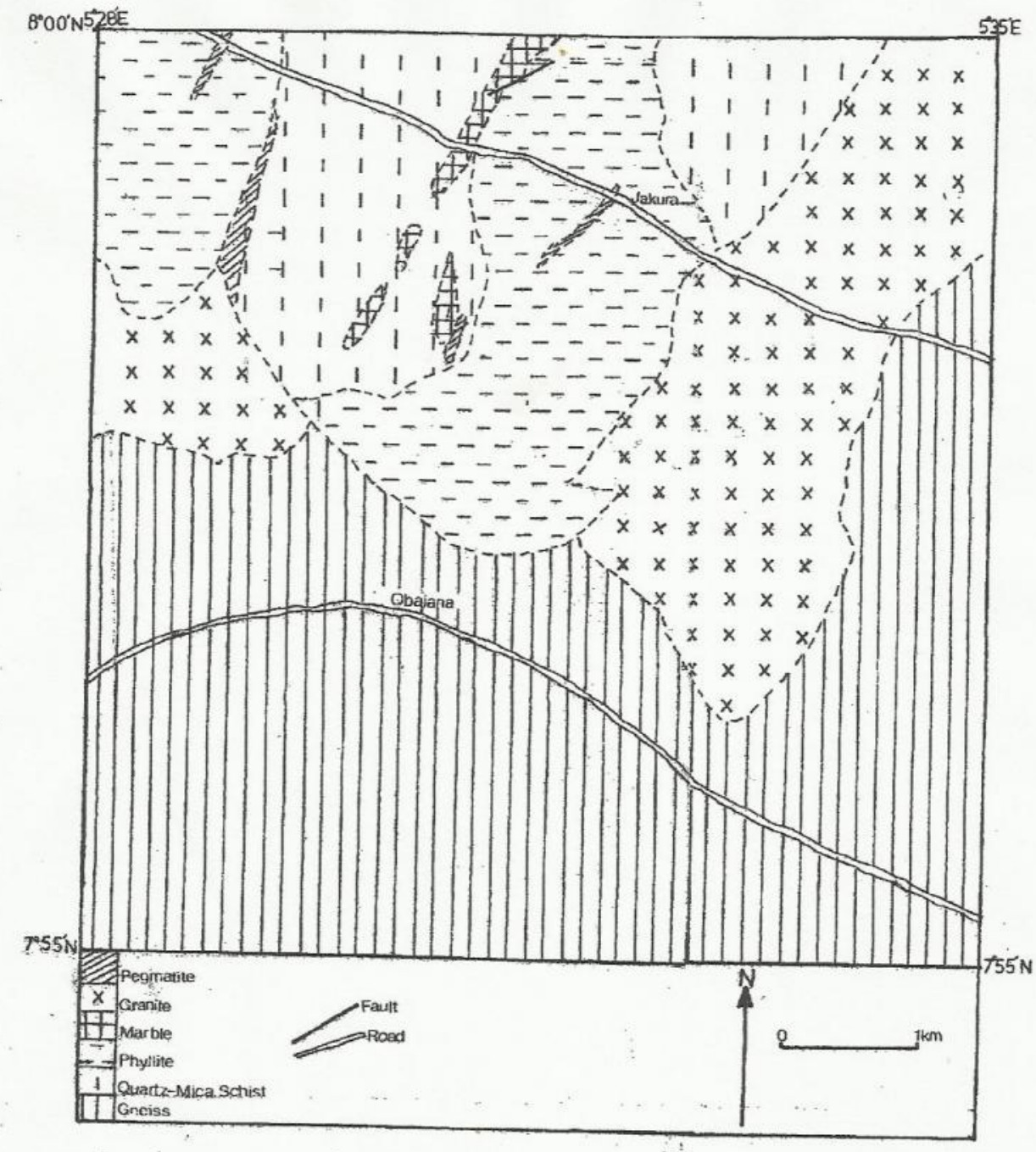

Fig. 2. Geological map of Jakura area (after Elueze and Okunlola 2003) 


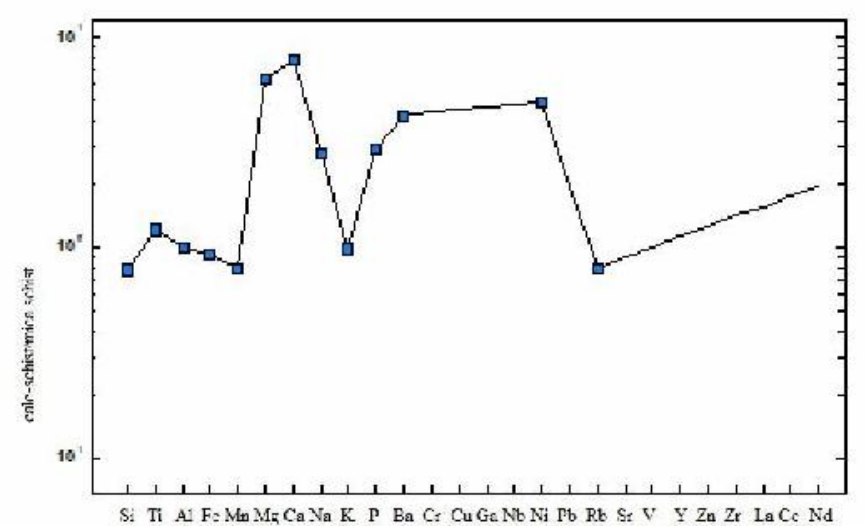

Fig. 3. Spiderdiagram comparing the composition of the calc-silicate schist with that of the Jakura mica schist

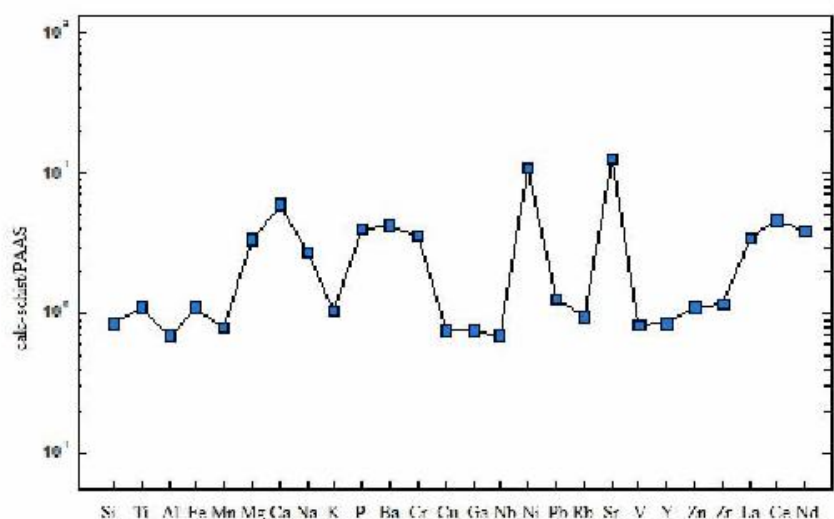

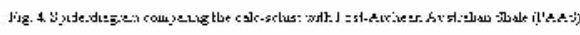

Fig. 4. Spiderdiagram comparing the composition of the calc-silicate schist with that of the Post-Archean Australian Shale (PAAS) 


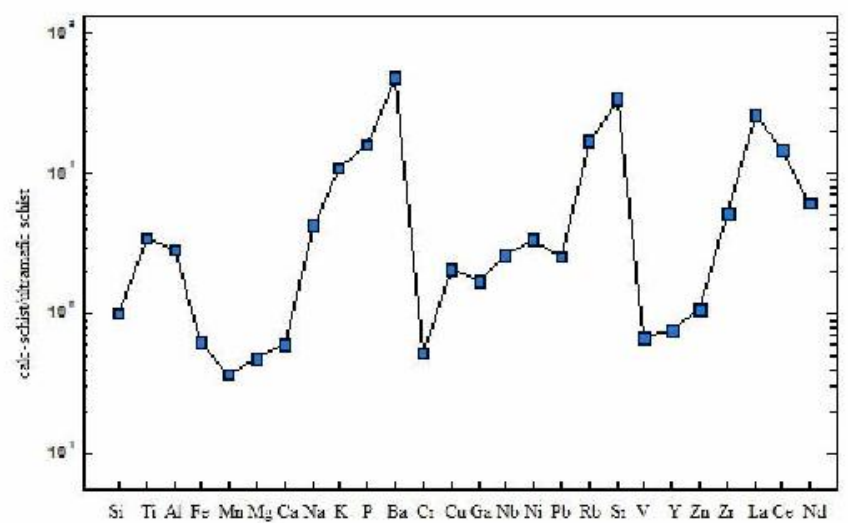

Fig. 5. Spiderdiagram comparing the composition of the calc-silicate schist with the ultramafic schist

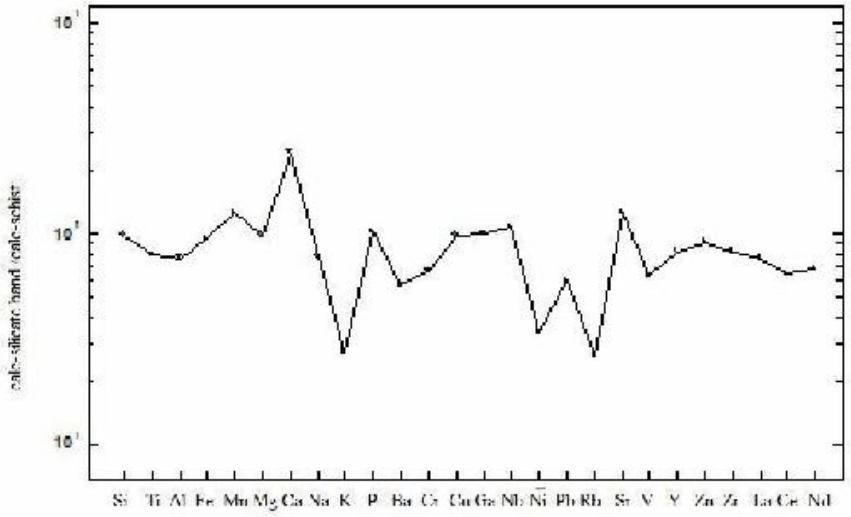

Fig. 6. Spiderdiagram comparig the composition of the calc-silicate band with that of the calc-silicate schist 


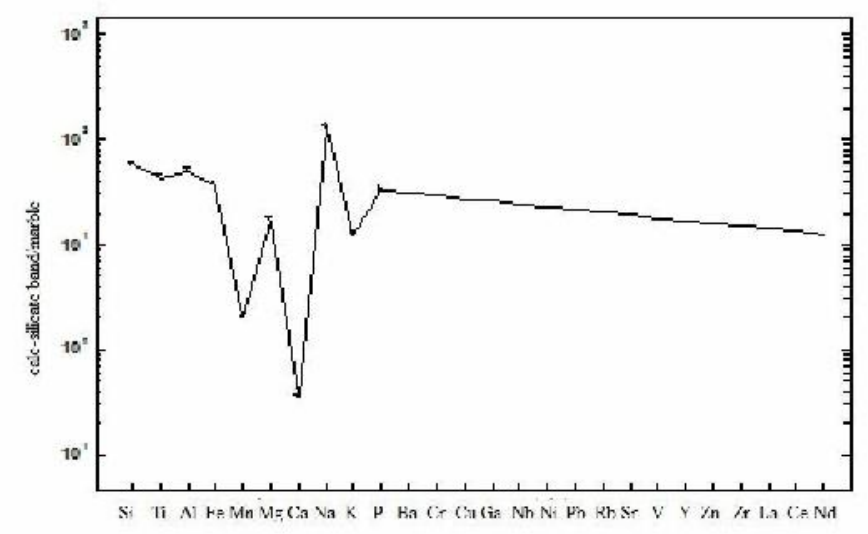

Fig. 7. Spiderdiagram comparing the composition of the calc-silicate band with that of the Jakura marble

Table1: Chemical compositions of the calc-silicate schists, calc-silicate reaction bands and ultramafic schists

$\begin{array}{lccccccccccc} & \mathrm{J} 1 & \mathrm{~J} 2 & \mathrm{~J} 3 & \mathrm{~J} 4 & \mathrm{~J} 5 & \mathrm{~J} 6 & \mathrm{JK} 4 & \mathrm{JK} 7 & \mathrm{JK} 8 & \mathrm{UJ1} & \text { UJ2 } \\ \mathrm{SiO}_{2} & 55.82 & 51.49 & 53.48 & 49.93 & 51.00 & 51.59 & 51.84 & 51.45 & 51.46 & 52.53 & 46.26 \\ \mathrm{TiO}_{2} & 1.11 & 0.99 & 1.10 & 1.10 & 1.16 & 1.11 & 0.78 & 1.05 & 0.78 & 0.32 & 1.62 \\ \mathrm{Al}_{2} \mathrm{O}_{3} & 13.70 & 10.51 & 13.86 & 12.71 & 13.25 & 12.98 & 9.10 & 9.43 & 11.03 & 4.60 & 9.95 \\ \mathrm{Fe}_{2} \mathrm{O}_{3} & 6.87 & 7.75 & 6.87 & 6.87 & 6.86 & 6.77 & 6.45 & 7.32 & 5.96 & 11.47 & 8.46 \\ \mathrm{MnO} & 0.09 & 0.13 & 0.07 & 0.07 & 0.06 & 0.07 & 0.10 & 0.10 & 0.09 & 0.22 & 0.07 \\ \mathrm{MgO} & 6.76 & 10.72 & 6.26 & 6.80 & 7.10 & 6.97 & 8.02 & 7.85 & 6.07 & 15.63 & 10.45 \\ \mathrm{CaO} & 6.62 & 8.90 & 6.43 & 7.33 & 9.08 & 8.34 & 20.30 & 17.43 & 18.70 & 12.92 & 9.99 \\ \mathrm{Na}_{2} \mathrm{O} & 4.19 & 1.71 & 4.07 & 3.22 & 3.43 & 3.30 & 2.36 & 2.30 & 3.11 & 0.79 & 0.68 \\ \mathrm{~K}_{2} \mathrm{O} & 3.08 & 6.43 & 3.16 & 3.57 & 2.78 & 3.35 & 0.51 & 1.68 & 0.88 & 0.34 & 5.70 \\ \mathrm{P}_{2} \mathrm{O}_{5} & 0.67 & 0.55 & 0.66 & 0.64 & 0.69 & 0.65 & 0.68 & 0.67 & 0.59 & 0.04 & 1.03 \\ \mathrm{Ba} & 2761 & 3867 & 2665 & 3478 & 3006 & 3599 & 836 & 2921 & 996 & 58 & 6784 \\ \mathrm{Cr} & 230 & 446 & 350 & 442 & 467 & 395 & 272 & 203 & 289 & 756 & 486 \\ \mathrm{Cu} & 40 & 44 & 31 & 28 & 40 & 39 & 38 & 35 & 34 & 18 & 5 \\ \mathrm{Ga} & 21 & 16 & 19 & 16 & 19 & 16 & 15 & 16 & 15 & 9 & 18 \\ \mathrm{Nb} & 11 & 8 & 16 & 12 & 16 & 14 & 15 & 16 & 11 & 5 & 20 \\ \mathrm{Ni} & 153 & 415 & 637 & 660 & 1050 & 692 & 202 & 236 & 175 & 178 & 710 \\ \mathrm{~Pb} & 25 & 15 & 33 & 25 & 27 & 26 & 10 & 20 & 16 & 10 & 16 \\ \mathrm{Rb} & 55 & 245 & 45 & 199 & 150 & 193 & 19 & 64 & 34 & 9 & 251 \\ \mathrm{Sr} & 2707 & 2121 & 2603 & 2543 & 2646 & 2501 & 2813 & 2810 & 3849 & 75 & 1566 \\ \mathrm{~V} & 114 & 116 & 124 & 120 & 128 & 125 & 68 & 88 & 71 & 183 & 128 \\ \mathrm{Y} & 24 & 19 & 24 & 26 & 25 & 22 & 16 & 23 & 17 & 31 & 33 \\ \mathrm{Zn} & 87 & 103 & 93 & 94 & 91 & 89 & 84 & 94 & 74 & 86 & 128 \\ \mathrm{Zr} & 199 & 160 & 287 & 283 & 268 & 259 & 170 & 227 & 200 & 47 & 354 \\ \mathrm{La} & 194 & 111 & 130 & 115 & 102 & 131 & 80 & 108 & 113 & 5 & 186 \\ \mathrm{Ce} & 407 & 228 & 427 & 336 & 379 & 417 & 196 & 266 & 250 & 25 & 543 \\ \mathrm{Nd} & 125 & 80 & 147 & 116 & 131 & 143 & 83 & 95 & 78 & 20 & 183\end{array}$

$\mathrm{J} 1, \mathrm{~J} 2, \mathrm{~J} 3, \mathrm{~J} 4, \mathrm{~J} 5, \mathrm{~J} 6$ are calc-silicate schists; JK4, JK7, JK8 are calc-silicate reaction bands; UJ1, UJ2 are ultramafic schists 
Table 2: Mean chemical compositions of the calc-silicate schist, calc-silicate reaction band, Jakura mica schist, Jakura marble and Average Post-Archean Shale (PAAS)

\begin{tabular}{|c|c|c|c|c|c|}
\hline \multicolumn{2}{|c|}{ Calc-schist } & Calc-silicate band & Mica sch & kura marble & PAAS \\
\hline $\mathrm{SiO}_{2}$ & 52.22 & 51.58 & 66.7 & 0.91 & 62.8 \\
\hline $\mathrm{TiO}_{2}$ & 1.09 & 0.87 & 0.90 & 0.02 & 1.0 \\
\hline $\mathrm{Al}_{2} \mathrm{O}_{3}$ & 12.84 & 9.85 & 12.84 & 0.20 & 18.9 \\
\hline $\mathrm{Fe}_{2} \mathrm{O}_{3}$ & 7.00 & 6.58 & 7.51 & 0.18 & 6.5 \\
\hline $\mathrm{MnO}$ & 0.08 & 0.10 & 0.10 & 0.05 & 0.1 \\
\hline $\mathrm{MgO}$ & 7.44 & 7.31 & 1.18 & 0.42 & 2.2 \\
\hline $\mathrm{CaO}$ & 7.78 & 18.81 & 1.00 & 54.01 & 1 \\
\hline $\mathrm{Na}_{2} \mathrm{O}$ & 3.32 & 2.59 & 1.19 & 0.02 & 1.2 \\
\hline $\mathrm{K}_{2} \mathrm{O}$ & 3.76 & 1.02 & 3.80 & 0.08 & 3.7 \\
\hline $\mathrm{P}_{2} \mathrm{O}_{5}$ & 0.64 & 0.65 & 0.22 & 0.02 & 0. \\
\hline $\mathrm{Ba}$ & 2778 & 1584 & 658 & - & 6 \\
\hline $\mathrm{Cr}$ & 388 & 255 & - & - & 110 \\
\hline $\mathrm{Cu}$ & 37 & 36 & - & - & 50 \\
\hline $\mathrm{Ga}$ & 15 & 15 & - & - & 20 \\
\hline $\mathrm{Nb}$ & 13 & 14 & - & - & 1 \\
\hline $\mathrm{Ni}$ & 601 & 204 & 123 & - & 5 \\
\hline $\mathrm{Pb}$ & 25 & 15 & - & - & 20 \\
\hline $\mathrm{Rb}$ & 149 & 39 & 188 & - & 16 \\
\hline $\mathrm{Sr}$ & 2520 & 3157 & - & - & 2 \\
\hline V & 121 & 76 & - & - & 15 \\
\hline $\mathrm{Y}$ & 23 & 19 & - & - & 2 \\
\hline $\mathrm{Zn}$ & 92 & 84 & - & - & 85 \\
\hline $\mathrm{Zr}$ & 243 & 199 & - & - & 210 \\
\hline $\mathrm{La}$ & 131 & 100 & - & - & $3 \varepsilon$ \\
\hline $\mathrm{Ce}$ & 366 & 237 & - & - & 8 \\
\hline $\mathrm{Nd}$ & 124 & 85 & - & - & 3 \\
\hline
\end{tabular}

\section{REFERENCES}

Ague, J., 2003. Fluid infiltration and transport of major, minor and trace elements during Regional metamorphism of carbonate rocks, Wepawaug Schist, Connecticut, USA. American Journal of Science, 303, 753-816.

Elueze, A. A. and Okunlola, O. A., 2003. Petrochemical and petrogenetic characteristics of metasedimentary rocks of Lokoja-Jakura Schist Belt, Central Nigeria. Journal of Mining and Geology, 39, 21-27.

Ferguson, C. C. and Al-Ameen, S. I., 1986. Geochemistry of Dalradian pelites from Connemara, Ireland: new constraints on kyanite genesis and conditions of metamorphism. Journal of the Geological Society of London, $143,237-252$.

Hazell, J. R. T., 1956. The Jakura Marble, Kabba Province. Records of the Geological Survey of Nigeria., pp 38-45.

Leake, B. E., 1980. Some metasomatic calc-magnesian silicate rocks from Connemara, western Ireland: mineralogical control of rock composition.

Taylor, S. R. and McLennan, S. M., 1985. The Continental Crust: its composition and evolution. Blackwell Scientific Publications, Oxford, 321pp.

Thompson, A. B., 1975. Calc-silicate diffusion zones between marble and pelitic schist. Journal of Petrology, 16, 314-346.

Turner, D. C., 1983. Upper Proterozoic Schist Belts in the Nigerian sector of the Pan-African province of West Africa. Precambrian Research, 21, 5579.

Van de Kamp, P. C., 1968. Geochemistry and origin of metasediments in the Haliburton-Madoc area, S.E. Ontario, Canada. Canadian Journal of Earth Sciences, 5, 1337-1372.

Van de Kamp, P. C. and Leake, B. E., 1986. Petrography and geochemistry of feldspathic and mafic sediments of the northeastern Pacific margin. Transactions of the Royal Society of Edinburgh: Earth Sciences, 76, 411-449.

Vearncombe, J. R., 1983. A proposed continental margin in the Precambrian of western Kenya. Geologische Rundschau, 72, 663-670. 